Kredo 4 (2021)
KREDO: Jurnal Ilmiah Bahasa dan Sastra
Terakreditasi Sinta 4 berdasarkan Keputusan
Direktorat Jenderal Penguatan Riset dan
$\begin{gathered}\text { Pengembangan, Kementerian Riset, Teknologi dan } \\ \text { Pendidikan Tinggi Republik Indonesia } \\ \text { Nomor: 23/E/KPT/2019. 08 Agustus 2019 } \\ \text { https://jurnal.umk.ac.id/index.php/kredo/index }\end{gathered}$

\title{
PENINGKATAN KEMAMPUAN MENULIS CERITA PENDEK MELALUI PENERAPAN METODE PARTISIPATORIS SISWA VII F SMPN 3 MAKASSAR
}

\author{
Sitti Aida Azis', Aziz Thaba² \\ sittiaidaazis@unismuh.ac.id \\ ${ }^{1}$ Universitas Muhammadiyah Makassar, Indonesia \\ ${ }^{2}$ Lembaga Swadaya Penelitian dan Pengembangan Pendidikan (LSP3) Matutu, Indonesia
}

Info Artikel
Sejarah Artikel
Diterima
3 Februari 2021
Disetujui
9 Maret 2021
Dipublikasikan
7 April 2021
Keywords
Ability, Writing Short
Stories, Parsipatoris

Kata Kunci

Kemampuan, Menulis Cerpen, Parsipatoris

\section{: Abstract}

- This research is a classroom action research whose subjects are class VII F students of SMPN 3 Makassar who assess 24 people. The object of research is the ability to write short stories by applying the participatory method. The aim of this study is to improve the students' ability to write short stories. The research steps including planning, implementing, observing, evaluating, and reflecting were carried out in two cycles. Data collection was carried out by using test techniques and non-test techniques. The test technique was used to measure the students' ability to write short stories after each cycle was carried out. Meanwhile, non-test techniques in the form of observation or observation are used to collect qualitative information during the cycle. Data analysis used proportional statistical techniques supported by qualitative descriptions. The results of the study proved that the short story writing skills of VII F students of SMPN 3 Makassar experienced a significant increase after learning to write short stories using a participatory approach in two cycles. This is evidenced by the average results, the mean value, the value that often appears, and the maximum value on the pre-action test, cycle I, cycle II, proving an increase in improvement. Thus, it can be denied that the participatory method is effectively used to improve learning outcomes in writing short stories for class VII F students of SMPN 3 Makassar.

:

Abstrak

Penelitian ini adalah penelitian tindakan kelas yang subjeknya adalah siswa kelas VII F SMPN 3 Makassar berjumlah 24 orang. Objek penelitiannya adalah kemampuan menulis cerita pendek dengan menerapkan metode parsipatoris Tujuan penelitian ini adalah meningkatkan kemampuan siswa menulis cerita pendek. Langkah-langkah penelitian meliputi perencanaan, pelaksanaan, observasi, evaluasi, dan refleksi yang dilaksanakan dalam dua siklus. Pengumpulan data dilakukan dengan teknik tes dan teknik non-tes. Teknik tes digunakan untuk mengukur kemampuan siswa menulis cerita pendek setelah setiap siklus dilaksanakan. Sedangkan teknik non tes berupa pengamatan atau observasi digunakan untuk mengumpulkan informasi kualitatif selama siklus berlangsung. Data dianalisis menggunakan teknik statistik persentase yang didukung dengan deskripsi kualitatif. Hasil penelitian membuktikan bahwa keterampilan menulis cerita pendek siswa VII F SMPN 3 Makassar mengalami peningkatan yang signifikan setelah dilaksanakan pembelajaran menulis cerita pendek menggunakan pendekatan partisipatoris dalam dua siklus. Hal tersebut dibuktikan dengan hasil rata-rata, nilai tengah, nilai yang sering muncul, serta nilai maksimal pada tes pra tindakan, siklus I, siklus II, membuktikan adanya peningkatan. Dengan demikian, dapat disimpulkan bahwa metode partisipatoris efektif digunakan untuk meningkatkan hasil belajar menulis cerita pendek siswa kelas VII F SMPN 3 Makassar. 


Kredo 4 (2021)
KREDO: Jurnal Ilmiah Bahasa dan Sastra
Terakreditasi Sinta 4 berdasarkan Keputusan
Direktorat Jenderal Penguatan Riset dan
Pengembangan, Kementerian Riset, Teknologi dan
Pendidikan Tinggi Republik Indonesia
Nomor: 23/E/KPT/2019.08 Agustus 2019
https://jurnal.umk.ac.id/index.php/kredo/index

\section{PENDAHULUAN}

Masalah pendidikan merupakan masalah yang sangat penting, karena pendidikan itu akan sangat berpengaruh terhadap perkembangan hidup manusia. Dengan semakin tinggi jenjang pendidikan yang ditempuh oleh seseorang maka semakin besar kesempatan untuk meraih sukses hidup di masa mendatang. Secara garis besarnya, pendidikan sangat berkompeten dalam kehidupan, baik kehidupan itu sendiri, keluarga, masyarakat maupun kehidupan bangsa dan negara.

Pemerintah dalam hal ini telah mengatur dan mengarahkan pendidikan nasional seperti yang tertuang dalam Undang-Undang Nomor 3450 tahun 2003 tentang Sistem Pendidikan Nasional. Dalam Pasal 3 menyebutkan tujuan dari pedidikan nasional yang berbunyi: Pendidikan nasional berfungsi mengembangkan kemampuan dan membentuk watak serta peradaban bangsa yang bermartabat dalam rangka mencerdaskan kehidupan bangsa, bertujuan untuk mencerdaskan kehidupan bangsa, berkembangnya potensi peserta didik agar menjadi manusia yang beriman dan bertakwa kepada Tuhan Yang Maha Esa, berakhlak mulia, sehat, berilmu, cakap, kreatif, mandiri, dan menjadi warga negara yang demokratis serta bertanggungjawab (Indonesia, 2003).

Pembangunan nasional yang sedang dilaksanakan bertujuan untuk membangun manusia Indonesia seutuhnya. Berhasil tidaknya program pembangunan faktor manusia memegang peranan yang sangat penting. Untuk pembangunan itu diperlukan manusia yang berjiwa pemikir, kreatif dan mau bekerja keras, memiliki pengetahuan dan ketrampilan serta memiliki pengetahuan dan ketrampilan serta memiliki sifat positif terhadap etos kerja

Sekolah sebagai tempat proses belajar mempunyai kedudukan yang sangat penting dalam dunia pendidikan (Julaeha, 2019). Oleh karena itu pendidikan di sekolah memegang peranan penting dalam rangka mewujudkan tercapainya pendidikan nasional secara optimal seperti yang diharapkan. Dalam proses belajar mengajar tersebut guru menjadi pemeran utama dalam menciptakan situasi interaktif yang edukatif, yakni interaksi antara guru dengan siswa, siswa dengan siswa dan sumber pembelajaran dalam menunjang tercapainya tujuan belajar.

Tujuan seperti yang telah tersebut di atas dapat dicapai dengan baik apabila pada diri peserta didik timbul suatu kesadaran yang mendalam untuk meraih prestasi yang tinggi. Untuk mencapai prestasi yang 


Kredo 4 (2021)
KREDO: Jurnal Ilmiah Bahasa dan Sastra
Terakreditasi Sinta 4 berdasarkan Keputusan
Direktorat Jenderal Penguatan Riset dan
Pengembangan, Kementerian Riset, Teknologi dan
Pendidikan Tinggi Republik Indonesia
Nomor: 23/E/KPT/2019. 08 Agustus 2019
https://jurnal.umk.ac.id/index.php/kredo/index

tinggi maka diperlukan proses interaksi yang optimal antara pendidik sebagai pentransfer ilmu dan peserta didik sebagai objek.

Pembelajaran apresiasi sastra merupakan bagian integral dari pembelajaran komponen pemahaman bahasa. Artinya, pembelajaran sastra terpusat pada pemahaman, penghayatan, dan penikmatan atas karya sastra.

Pembelajaran

sastra

dimaksudkan untuk meningkatkan kemampuan siswa mengapresiasikan karya sastra. Kegiatan mengapresiasikan sastra berkaitan erat dengan pelatihan mempertajam perasaan, penalaran, dan daya khayal, serta kepekaan terhadap masyarakat, budaya, dan lingkungan hidup. Untuk memahami dan menghayati karya sastra, siswa diharapkan langsung membaca karya sastra bukan membaca ringkasannya (Minderop, 2010).

Terkait dengan pembelajaran apresiasi sastra, perlu dipertimbangkan alternatif atau pilihan kegiatan seperti membaca diam (dalam hati), membacakan puisi, prosa, atau drama, mendeklamasikan puisi, membahas isi, bentuk, bahasa, tema, dan alinan, menafsirkan isi, mendengarkan sandiwara radio, memerankan atau bermain peran, melakonkan, mendiskusikan, benpantun, membuat ikhisar, melisankan, melagukan puisi, membandingkan, mengelompokkan dan membedakan isi, bentuk, tema, dan

331 | Jurnal Kredo

Vol. 4 No. 22021 corak, menemukan pesan dan amanat, membuat resensi atau pertimbangan, menciptakan puisi, cerpen, atau drama, menulis skenario, membuat syair lagulagu, menyadur karya sastra (bukan pengetahuan tentang sastra), menonton dan membicarakan film yang bendasarkan karya sastra, menghadiri acara budaya, membuat dan menyelenggarakan kegiatan sastra drama, lomba puisi, dan deklamasi, mendengarkan pembacaan cerpen, mengadakan lomba drama dalam kelas, melakonkan drama dan improvisasi, mengumpulkan cerita-cerita rakyat setempat, membuat majalah dinding tentang sastra, membuat majalah sekolah (Pramesthi, 2011).

Berdasarkan rangkaian konsep dan pandangan di atas, dapat kita simpulkan bahwa sastra memiliki fungsi dan peran yang sangat penting dalam proses perkembangan dan pembelajaran siswa. oleh karena itu, sastra dirasa penting untuk dibelajarkan secara sinergis sehingga fungsi dan perannya tercapai secara optimal. Kesinergisan fungsi dan tujuan tersebut tentu harus ditunjang oleh beberapa faktor diantaranya pengelolahan kelas belajar yang baik. Pengelolahan kelas belajar dalam hal ini berkaitan dengan penerapan metode yang tepat guna dalam memberikan pengalaman dan pengetahuan siswa. 


Kredo 4 (2021)
KREDO: Jurnal Ilmiah Bahasa dan Sastra
Terakreditasi Sinta 4 berdasarkan Keputusan
Direktorat Jenderal Penguatan Riset dan
Pengembangan, Kementerian Riset, Teknologi dan
Pendidikan Tinggi Republik Indonesia
Nomor: 23/E/KPT/2019. 08 Agustus 2019
https://jurnal.umk.ac.id/index.php/kredo/index

\section{KAJIAN TEORI}

\section{A. Hakikat Menulis}

Menurut Semi (2007) menulis adalah suatu aktivitas bahasa yang menggunakan tulisan sebagai mediumnya. Menulis pada hakikatnya adalah suatu proses berpikir yang teratur, sehingga apa yang ditulis mudah dipahami pembaca. Sebuah tulisan dikatakan baik apabila memiliki ciri-ciri, antara lain bermakna, jelas, bulat dan utuh, ekonomis, dan memenuhi kaidah gramatika.

Kegiatan menulis merupakan keterampilan mekanis yang dapat dipahami dan dipelajari. Menulis sebagai suatu proses terdiri atas beberapa tahapan. Tompkins (1994) dan Ellis dkk. (1989) dalam Hutagalung (2017) menguraikan lima tahapan menulis, yaitu pra-menulis, pengedrafan, perbaikan, penyuntingan, dan publikasi. Kegiatan menulis dilakukan dengan berbagai tujuan. Menulis mempunyai empat tujuan, yaitu untuk mengekpresikan diri, memberikan informasi kepada pembaca, mempersuasi pembaca, dan untuk menghasilkan karya tulis. Berkaitan dengan manfaat menulis, Dalman (2021) mengemukakan bahwa: (1) menulis menyumbang kecerdasan, (2) menulis mengembangkan daya inisiatif dan kreativitas, (3) menulis menumbuhkan keberanian, dan (4) menulis mendorong kemauan dan kemampuan mengumpulkan informasi.

\section{B. Cerpen}

Edgar Allan Poe, Jassin (1961:72) dalam Raditiyanto (2018) mengemukakan cerpen adalah sebuah cerita yang selesai dibaca dalam sekali duduk, kira-kira berkisar antara setengah sampai dua jam. Cerpen ialah karya sastra yang memuat penceritaan secara memusat kepada suatu peristiwa pokok saja. Semua peristiwa lain yang diceritakan dalam sebuah cerpen, tanpa kecuali ditujukan untuk mendukung peristiwa pokok.

Unsur-unsur intrinsik karya sastra berbentuk cerpen, adalah unsurunsur pembangun struktur cerpen yang ada di dalam cerpen itu sendiri, yakni : (1) tema, (2) tokoh, (3) alur, (4) latar, (5) teknik penceritaan, dan (6) diksi. M. Atar Semi berpendapat bahwa struktur ekstrinsik mencakapi faktor sosialekonomi, faktor kebudayaan, faktor sosio-politik, kegamaan, dan tata nilai yang dianut dalam masyarakat (Raditiyanto, 2018).

\section{Metode}

\section{Partisipatoris}

Pembelajaran Partisipatoris (Participative Teaching and Learning) "merupakan metode pembelajaran yang melibatkan peserta didik secara aktif dalam perencanaan, pelaksanaan, dan evaluasi pembelajaran". Pembelajaran partisipatoris pada intinya dapat diartikan sebagai upaya atau cara pendidik untuk mengikutsertakan 


Kredo 4 (2021)
KREDO: Jurnal Ilmiah Bahasa dan Sastra
Terakreditasi Sinta 4 berdasarkan Keputusan
Direktorat Jenderal Penguatan Riset dan
Pengembangan, Kementerian Riset, Teknologi dan
Pendidikan Tinggi Republik Indonesia
Nomor: 23/E/KPT/2019. 08 Agustus 2019
https://jurnal.umk.ac.id/index.php/kredo/index

peserta didik dalam kegiatan pembelajaran yang meliputi tiga tahap, yaitu tahap perencanaan program, pelaksanaan program dan penilaian program (Sadari, 2015)

Pembelajaran partispatif adalah kegiatan pembelajaran di mana semua pihak, termasuk pendidik dan peserta didik, terlibat secara aktif dalam setiap kegiatan pembelajaran (Sari, 2015). Keikutsertaan peserta didik itu diwujudkan dalam tiga tahapan kegiatan pembelajaran yaitu tahap perencanaan program (program planning), pelaksanaan (program implementtion), dan penilaian (program evaluation) kegiatan pembelajaran.

\section{METODE PENELITIAN}

\section{Jenis Penelitian}

Penelitian ini dilaksanakan dengan menggunakan metode penelitian tindakan kelas. Penelitian ini berusaha mengkaji dan merefleksi suatu pendekatan pembelajaran dengan tujuan untuk meningkatkan proses dan produk pengajaran di kelas. Hopkins (Rochiati, 2008:11) mengartikan penelitian tindakan kelas untuk mengidentifikasi penelitian kelas yang mengkombinasikan prosedur penelitian dengan tindakan substansif, suatu tindakan yang dilakukan dalam disiplin inkuiri, atau suatu usaha seseorang untuk memahami apa yang terjadi,

\section{3 | Jurnal Kredo}

Vol. 4 No. 22021 sambil terlibat dalam sebuah proses perbaikan dan perubahan.

Penelitian ini dilaksanakan dengan menitikberatkan pada proses bagaimana siswa dapat terampil dalam menulis cerpen dan dengan hasil yang lebih baik pula dengan menerapkan metode partisipatoris. Objek dalam penelitian tindakan kelas (PTK) ini adalah kemampuan menulis cerpen. Adapun subjek penelitiannya adalah siswa VII F SMPN 3 Makassar yang dipilih dengan teknik random atau acak sebanyak 24 orang siswa. Teknik pengumpulan data pada penelitian tindakan kelas ini berupa teknik tes dan teknik nontes.

\section{Desain Penelitian}

Desain pelaksanaan PTK mengadaptasi model penelitian tindakan kelas Kemmis \& Me Taggart yang memiliki empat tahapan dasar yang harus dilakukan yaitu (1) perencanaan, (2) tindakan (pelaksanaan), (3) obervasi, dan (4) refleksi (Wibawa, 2003). Ke empat tahap tersebut merupakan siklus atau daur, oleh karena itu setiap tahap akan berulang kembali.

\section{Pengaturan dan Subjek Penelitian}

Penelitian ini dilaksanakan dengan menitikberatkan pada proses menjawab masalah; bagaimana siswa dapat terampil dalam menulis cerpen dengan menggunakan metode partisipatoris. Adapun subjek penelitian 


Kredo 4 (2021)
KREDO: Jurnal Ilmiah Bahasa dan Sastra
Terakreditasi Sinta 4 berdasarkan Keputusan
Direktorat Jenderal Penguatan Riset dan
Pengembangan, Kementerian Riset, Teknologi dan
Pendidikan Tinggi Republik Indonesia
Nomor: 23/E/KPT/2019. 08 Agustus 2019
https://jurnal.umk.ac.id/index.php/kredo/index

PTK ini adalah siswa kelas VII F SMP Negeri 3 Makassar.

\section{Teknik Pengumpulan Data}

Pengumpulan data dalam penelitian tindakan kelas ini menggunakan teknik tes dan nontes. Teknik tes digunakan untuk mengetahui peningkatan kemampuan siswa menulis cerita pendek. Sedangkan teknik nontes yang digunakan adalah pengamatan atau observasi dan dokumentasi. Pengamatan dilakukan untuk memperoleh gambaran proses pembelajaran atau pemberian tindakan di kelas. Sedangkan dokumentasi digunakan untuk mengumpulkan data-data pendukung dalam bentuk dokumen, baik dokumen tertulis atau dalam bentuk gambara dan video.

\section{Tekni Analisis Data}

Data dalam penelitian ini dianalisis dalam dua teknik yaitu teknik deskriptif dan teknik statistik persentase. Teknik deskriptif digunakan untuk menjabarkan seluruh data atau informasi kualitatif yang diperoleh dalam penelitian seperti data hasil pengamatan. Selain itu, teknik deskriptif juga digunakan untuk untuk menguraikan data atau informasi hasil analisis kuantitatif. Analisis dengan teknik statistik persentase digunakan untuk menjabarkan data kuantitatif yang diperoleh melalui tes, sehingga informasi peningkatan kemampuan siswa dapat diketahui.

\section{HASIL DAN PEMBAHASAN}

\section{A. Hasil Tes Pratindakan}

Hasil tes pratindakan dimaksudkan untuk mengukur kemampuan awal siswa dalam menulis cerita pendek. Ada tujuh aspek yang dinilai dalam tes pratindakan ini. Aspek tersebut sesuai dengan aspek yang telah diuraikan sebelumnya. Adapun hasil tes pratindakan tersebut adalah sebagai berikut;

Tabel 1 Rangkuman Hasil Tes Pratindakan Menulis Cerita pendek

\begin{tabular}{|c|c|c|c|c|c|c|c|c|c|}
\hline \multirow{3}{*}{$\begin{array}{c}\text { Sam } \\
\text { pel }\end{array}$} & \multicolumn{7}{|c|}{ Aspek Yang Dinilai } & $\begin{array}{c}\text { Sko } \\
\text { r }\end{array}$ & $\begin{array}{c}\text { Sko } \\
\mathrm{r}\end{array}$ \\
\hline & \multirow[t]{2}{*}{1} & \multirow[t]{2}{*}{2} & \multirow[t]{2}{*}{3} & \multirow[t]{2}{*}{4} & \multirow[t]{2}{*}{5} & \multirow[t]{2}{*}{6} & \multirow[t]{2}{*}{7} & Tota & Akh \\
\hline & & & & & & & & 1 & ir \\
\hline \multirow{2}{*}{01} & 4 & 5 & 3 & 3 & 6 & 2 & 2 & 35,7 & 36 \\
\hline & 0 & 0 & 0 & 0 & 0 & 0 & 0 & 1 & \\
\hline \multirow{2}{*}{02} & 3 & 2 & 6 & 5 & 3 & 2 & 2 & 32,8 & 33 \\
\hline & 0 & 0 & 0 & 0 & 0 & 0 & 0 & 5 & \\
\hline \multirow{2}{*}{03} & 2 & 5 & 3 & 2 & 3 & 3 & 3 & \multirow{2}{*}{30} & 30 \\
\hline & 0 & 0 & 0 & 0 & 0 & 0 & 0 & & \\
\hline \multirow{2}{*}{04} & 5 & 2 & 1 & 2 & 3 & 6 & 3 & 31,4 & 31 \\
\hline & 0 & 0 & 0 & 0 & 0 & 0 & 0 & 2 & \\
\hline \multirow{2}{*}{05} & 3 & 6 & 2 & 4 & 5 & 6 & 2 & \multirow{2}{*}{40} & 40 \\
\hline & 0 & 0 & 0 & 0 & 0 & 0 & 0 & & \\
\hline \multirow{2}{*}{06} & 5 & 2 & 3 & 6 & 2 & 1 & 2 & \multirow{2}{*}{30} & 30 \\
\hline & 0 & 0 & 0 & 0 & 0 & 0 & 0 & & \\
\hline \multirow{2}{*}{07} & 2 & 3 & 6 & 3 & 2 & 3 & 3 & 31 & 31 \\
\hline & 0 & 0 & 0 & 0 & 0 & 0 & 0 & 42 & \\
\hline \multirow{2}{*}{08} & 2 & 2 & 3 & 4 & 2 & 3 & 3 & 41 & 41 \\
\hline & 0 & 0 & 0 & 0 & 0 & 0 & 0 & 42 & \\
\hline
\end{tabular}




Kredo 4 (2021)
KREDO: Jurnal Ilmiah Bahasa dan Sastra
Terakreditasi Sinta 4 berdasarkan Keputusan
Direktorat Jenderal Penguatan Riset dan
Pengembangan, Kementerian Riset, Teknologi dan
Pendidikan Tinggi Republik Indonesia
Nomor: 23/E/KPT/2019. 08 Agustus 2019
https://jurnal.umk.ac.id/index.php/kredo/index

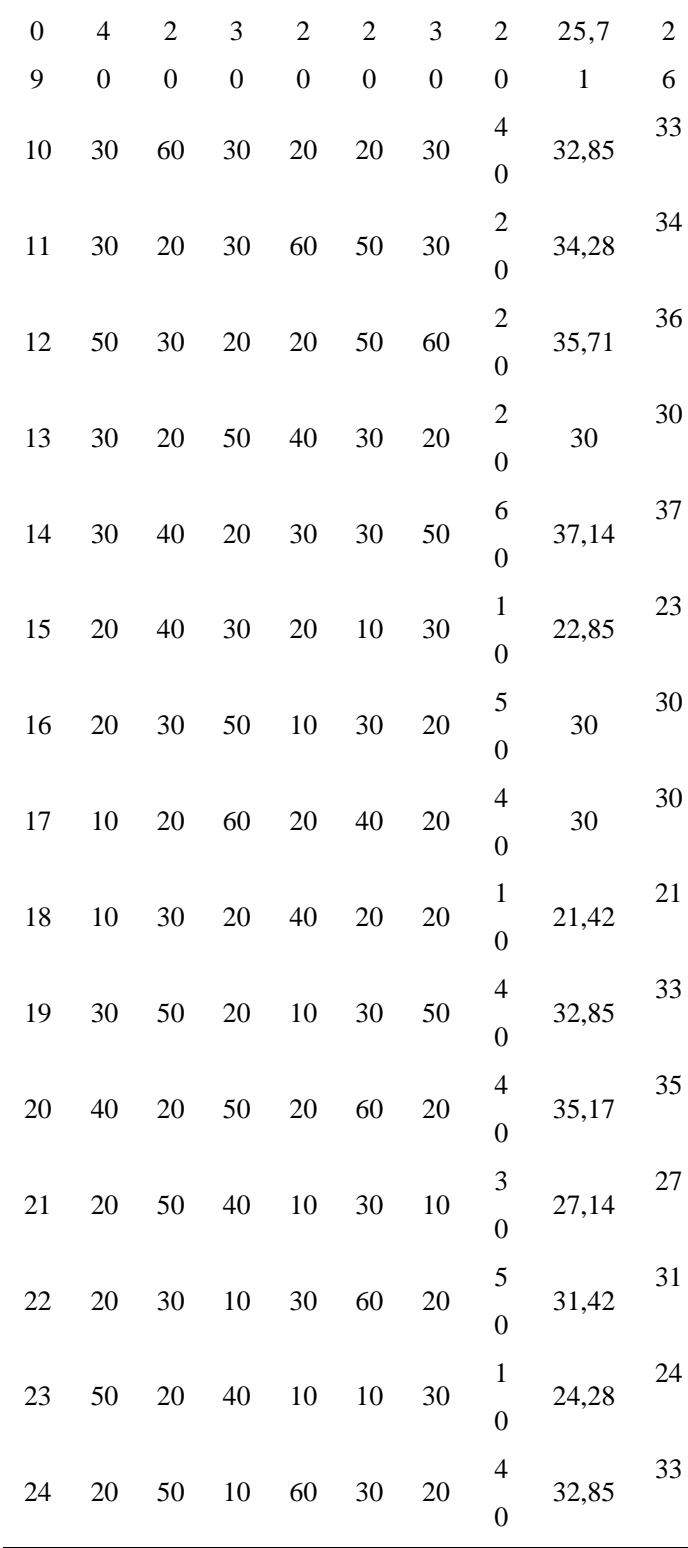

Dari tabel rangkuman data di atas dapat diuraikan bahwa data yang diperoleh dari 24 sampel dengan menggunakan 7 aspek penilaian yang mendapat nilai skor total $40 \%$ sampai 41,42\% dengan skor akhir 40 dan 41 diperoleh sampel 05 dan 08, selanjutnya untuk nilai skor total 30\%, 31,42\%, $32,85 \%, 34,28 \%, 35,17 \%, 35,71 \%$, dan
37,14\%, diperoleh sampel 03, 06, 13, 16, 17 masing-masing skor akhir 30, sampel 04, 07, 22 dengan skor akhir 31, sampel 02, 10, 19, 24 masing-masing skor akhir 33, sampel 11 skor akhir 34, sampel 01, 12 skor akhir 36 dan sampel 20 dengan skor akhir 35, sampel 14 dengan nilai skor akhir 37, Selanjutnya sampel yang mendapat nilai dibawa rata-rata skor akhir 30 diperoleh sampel 21 skor total $27,14 \%$ dengan skor akhir 27 , sampel 09 skor total $25,71 \%$ dengan skor akhir 26, sampel 23 skor total $24,28 \%$ skor akhir 24, sampel 15 skor total $22,85 \%$ skor akhir 23 , sedangkan skor total 21,42\% dengan skor akhir 21 diperoleh sampel 18 .

Tabel 2 Data Statistik Tes Pratindakan

\begin{tabular}{c|c}
\hline Statistik & Skor \\
Mean & 32,36 \\
Median & 32,85 \\
Modus & 30 \\
Minimum & 21 \\
Maksimum & 41 \\
Total & 777 \\
\hline \multicolumn{2}{|c|}{ Dari tabel di atas dapat diuraikan }
\end{tabular}
bahwa data yang diperoleh dari 24 sampel diperoleh rata-rata sebesar 32,36. Nilai yang sering muncul adalah 30 , nilai tengah adalah 32,85 . Adapun nilai tertinggi atau maksimum adalah 41 dan nilai terendah adalah 21. Adapun total keseluruhan skor yang diperoleh adalah 777. Selanjutnya tabel frekuensi data pratindakan adalah sebagai berikut: 


Kredo 4 (2021)
KREDO: Jurnal Ilmiah Bahasa dan Sastra
Terakreditasi Sinta 4 berdasarkan Keputusan
Direktorat Jenderal Penguatan Riset dan
Pengembangan, Kementerian Riset, Teknologi dan
Pendidikan Tinggi Republik Indonesia
Nomor: 23/E/KPT/2019. 08 Agustus 2019
https://jurnal.umk.ac.id/index.php/kredo/index

Tabel 3 Frekuensi Data Tindakan

\begin{tabular}{cccc}
\hline $\begin{array}{c}\text { Nilai } \\
\text { akhir }\end{array}$ & Frekuensi & Persentase & $\begin{array}{c}\text { Persentase } \\
\text { komulatif }\end{array}$ \\
\hline 21 & 1 & 4,2 & 4,2 \\
23 & 1 & 4,2 & 8,3 \\
26 & 1 & 4,2 & 12,5 \\
30 & 5 & 20,8 & 33,3 \\
31 & 3 & 12,5 & 45,8 \\
33 & 3 & 12,5 & 58,3 \\
33 & 1 & 4,2 & 62,5 \\
34 & 2 & 8,3 & 70,8 \\
35 & 1 & 4,2 & 75,0 \\
36 & 1 & 4,2 & 79,2 \\
36 & 1 & 4,2 & 83,3 \\
37 & 2 & 8,3 & 91,7 \\
40 & 1 & 4,2 & 95,8 \\
41 & 1 & 4,1 & 100,0 \\
Total & 24 & 100 & \\
\hline \multicolumn{5}{c}{ Dari tabel di atas dapat diuraikan }
\end{tabular}

bahwa nilai $21,23,26,33,35,36,36$, 40, 41, diperoleh masing-masing 1 orang sampel dengan persentase masing-masing 4,2\%. Selanjutnya untuk nilai 34 dan 37 masing-masing di peroleh 2 orang dengan persentase 8,3\%. Untuk nilai 31 dan 33 di peroleh masing-masing 3 orang sampel dengan persentase masing-masing $12,5 \%$. Selanjutnya untuk nilai 30 diperoleh 5 orang sampel dengan persentase $20,8 \%$.

\section{B. Hasil Observasi Pratindakan}

Selain data yang diperoleh melalui tes pratindakan juga diperoleh data hasil observasi. Data hasil observasi dibagi atas dua yaitu data observasi guru praktikan (peneliti) dan data observasi terhadap sampel. Lembar observasi ini dilakukan oleh guru kelas sebagai rekan kerja peneliti. Namun observasi yang dilakukan oleh guru ahli hanya pada saat proses pembelajaran dengan pendekatan partisipatoris dilaksanakan. Selain itu, observasi pratindakan dilakukan oleh peneliti.

Tabel 4 Hasil Observasi Yang Diberikan Kepada Guru Ahli

\begin{tabular}{|c|c|c|c|c|c|}
\hline \multirow{2}{*}{$\begin{array}{c}\text { Aspek yang } \\
\text { Dinilai }\end{array}$} & \multicolumn{5}{|c|}{ Kategori } \\
\hline & $\mathrm{Sb}$ & B & $\mathrm{Cb}$ & $\mathrm{Kb}$ & $\mathrm{Tb}$ \\
\hline $\begin{array}{c}\text { Kemampuan } \\
\text { membuka } \\
\text { pengajaran }\end{array}$ & & & & & \\
\hline $\begin{array}{l}\text { Proses } \\
\text { penyampaian } \\
\text { materi }\end{array}$ & & & & $\checkmark$ & \\
\hline $\begin{array}{c}\text { Interaksi } \\
\text { dengan siswa }\end{array}$ & & & & $\checkmark$ & \\
\hline $\begin{array}{l}\text { Kemampuan } \\
\text { pengelolahan } \\
\text { kelas }\end{array}$ & & & & $\checkmark$ & \\
\hline $\begin{array}{c}\text { Kemampuan } \\
\text { penguasaan } \\
\text { materi }\end{array}$ & & & & $\checkmark$ & \\
\hline $\begin{array}{l}\text { Kemampuan } \\
\text { menutup } \\
\text { pelajaran }\end{array}$ & & & & & \\
\hline
\end{tabular}

Dari tabel di atas dapat diuraikan bahwa kemampuan guru ahli dalam membuka pelajaran dinilai cukup baik. Disamping itu kemampuan mentransformasikan materi kepada siswa juga masih kurang baik. Selanjutnya interaksi yang dilakukan oleh peneliti kepada siswa dalam proses pembelajaran pun masih kurang baik, begitu pula dengan pengelolahan kelas dan penguasaan materi atau bahan pelajaran. Adapun kemampuan menutup pelajaran juga dalam kategori cukup baik. Adapun hasil observasi terhadap sampel penelitian seperti yang 


Kredo 4 (2021)
KREDO: Jurnal Ilmiah Bahasa dan Sastra
Terakreditasi Sinta 4 berdasarkan Keputusan
Direktorat Jenderal Penguatan Riset dan
Pengembangan, Kementerian Riset, Teknologi dan
Pendidikan Tinggi Republik Indonesia
Nomor: 23/E/KPT/2019. 08 Agustus 2019
https://jurnal.umk.ac.id/index.php/kredo/index

terangkum dalam tabel berikut;

Tabel 5 Data Hasil Observasi Terhadap Siswa Sampel

\begin{tabular}{|c|c|c|c|c|}
\hline \multirow{2}{*}{ Aspek yang Dinilai } & \multicolumn{4}{|c|}{ Kategori } \\
\hline & $\mathrm{Sb}$ & B $\quad \mathrm{Cb}$ & $\mathrm{Kb}$ & $\mathrm{Tb}$ \\
\hline $\begin{array}{c}\text { Antusias siswa } \\
\text { mengikuti pelajaran }\end{array}$ & & & ya & \\
\hline $\begin{array}{l}\text { Kemampuan siswa } \\
\text { mengkomunikasikan } \\
\text { ide }\end{array}$ & & & & \\
\hline $\begin{array}{l}\text { Keaktifan siswa } \\
\text { dalam kelas }\end{array}$ & & & ya & \\
\hline $\begin{array}{c}\text { Keterampilan } \\
\text { bertanya }\end{array}$ & & & ya & \\
\hline $\begin{array}{l}\text { Keterampilan } \\
\text { menjawab }\end{array}$ & & & ya & \\
\hline $\begin{array}{l}\text { Keterampilan } \\
\text { memberikan solusi }\end{array}$ & & & ya & \\
\hline
\end{tabular}

Dari tabel di atas, dapat diuraikan bahwa antusias siswa saat mengikuti pelajaran kurang baik, siswa cenderung diam, keluar masuk ruangan, serta beberapa diantaranya bermain-main. Kemampuan siswa mengkomunikasikan ide yang diamati sangat buruk, siswa hanya berperan sebagai pendengar pasif. Keaktifan siswa dalam kelas dalam kegiatan pembelajaran kurang baik, masih ada siswa yang aktif, namun hanya siswa yang dianggap unggul. Dari hasil observasi keterampilan bertanya siswa masih kurang baik. Mereka cenderung menerima apa saja yang dijelaskan dan diperintahkan oleh guru. Hal serupa pun sama dengan kemampuan menjawab dan memberikan solusi.

\section{Hasil Tes Siklus I}

Hasil tes Siklus I dimaksudkan untuk mengukur kemampuan tahap pertama siswa setelah memperoleh perlakuan awal dalam menulis cerita pendek. Ada tujuh aspek yang dinilai dalam tes pratindakan ini. Aspek tersebut sesuai dengan aspek yang telah diuraikan sebelumnya. Adapun hasil tes tersebut adalah sebagai berikut;

Tabel 6 Rangkuman Hasil Tes Siklus I Menulis Cerita pendek

\begin{tabular}{|c|c|c|c|c|c|c|c|c|c|}
\hline \multirow{2}{*}{ Sampel } & \multicolumn{7}{|c|}{ Aspek Yang Dinilai } & \multirow{2}{*}{$\begin{array}{l}\text { Skor } \\
\text { Total }\end{array}$} & \multirow{2}{*}{$\begin{array}{l}\text { Skor } \\
\text { Akhir }\end{array}$} \\
\hline & 1 & 2 & 3 & 4 & 5 & 6 & 7 & & \\
\hline 01 & 50 & 50 & 10 & 50 & 60 & 30 & 30 & 40 & 40 \\
\hline 02 & 50 & 30 & 60 & 50 & 40 & 20 & 30 & 40 & 40 \\
\hline 03 & 40 & 50 & 40 & 30 & 30 & 40 & 60 & 41,42 & 41 \\
\hline 04 & 50 & 40 & 20 & 30 & 30 & 60 & 50 & 40 & 40 \\
\hline 05 & 60 & 60 & 20 & 50 & 60 & 60 & 30 & 48,57 & 49 \\
\hline 06 & 50 & 40 & 40 & 60 & 20 & 20 & 30 & 37,14 & 37 \\
\hline 07 & 40 & 50 & 60 & 30 & 40 & 30 & 50 & 42,85 & 43 \\
\hline 08 & 50 & 40 & 30 & 40 & 50 & 30 & 40 & 40 & 40 \\
\hline 09 & 60 & 30 & 50 & 20 & 50 & 30 & 40 & 40 & 40 \\
\hline 10 & 40 & 60 & 50 & 20 & 30 & 30 & 50 & 40 & 40 \\
\hline 11 & 30 & 50 & 30 & 60 & 60 & 30 & 40 & 42,85 & 43 \\
\hline 12 & 50 & 30 & 20 & 40 & 50 & 60 & 50 & 42,85 & 43 \\
\hline 13 & 30 & 30 & 50 & 40 & 50 & 20 & 40 & 37,14 & 37 \\
\hline 14 & 30 & 40 & 50 & 60 & 30 & 50 & 60 & 52,85 & 53 \\
\hline 15 & 50 & 40 & 50 & 20 & 30 & 30 & 20 & 34,28 & 34 \\
\hline 16 & 60 & 30 & 50 & 20 & 30 & 40 & 60 & 41,42 & 41 \\
\hline 17 & 30 & 20 & 60 & 30 & 40 & 60 & 40 & 40 & 40 \\
\hline 18 & 40 & 30 & 20 & 40 & 20 & 30 & 50 & 32,85 & 33 \\
\hline 19 & 40 & 50 & 60 & 40 & 30 & 50 & 40 & 44,28 & 44 \\
\hline 20 & 40 & 50 & 50 & 40 & 60 & 50 & 40 & 47,14 & 47 \\
\hline 21 & 30 & 50 & 40 & 30 & 30 & 40 & 30 & 35,71 & 33 \\
\hline 22 & 20 & 30 & 10 & 30 & 60 & 30 & 50 & 32,85 & 33 \\
\hline 23 & 50 & 40 & 40 & 30 & 20 & 30 & 20 & 32,85 & 33 \\
\hline 24 & 60 & 50 & 40 & 60 & 30 & 30 & 40 & 44,28 & 44 \\
\hline
\end{tabular}

Dari tabel di atas dengan menggunakan 7 aspek penilaian dapat diuraiankan bahwa nilai skor akhir 40 diperoleh 7 orang sampel, 4 orang dengan skor akhir 33, dua orang sampel dengan skor akhir 41, dua orang sampel dengan skor akhir 44, satu orang sampel dengan skor akhir 49. Begitu pula dengan skor 47, 34, dan 53 yang masing-masing diperoleh satu orang siswa.

\section{7 | Jurnal Kredo \\ Vol. 4 No. 22021}




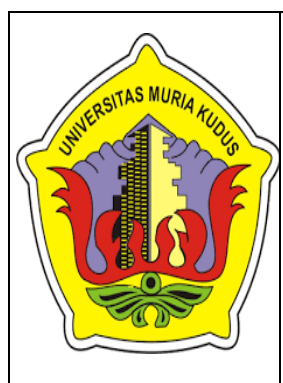

Kredo 4 (2021)

KREDO: Jurnal Ilmiah Bahasa dan Sastra

Terakreditasi Sinta 4 berdasarkan Keputusan

Direktorat Jenderal Penguatan Riset dan

Pengembangan, Kementerian Riset, Teknologi dan

Pendidikan Tinggi Republik Indonesia

Nomor: 23/E/KPT/2019. 08 Agustus 2019

https://jurnal.umk.ac.id/index.php/kredo/index

Dari tabel rangkuman data di atas akan dibuatkan tabel frekuensi dan statistik. Tabel frekuensi akan memuat satuan-satuan skor yang diperoleh siswa, frekuensi perolehan setiap skor, persentase perolehan dan persentase komulatif. Selanjutnya pada data tabel statistik akan memuat rata-rata (mean), nilai tengah (median), nilai yang sering muncul (modus), nilai maksimal (maksimum), dan nilai minumal (minimum). Adapun tabel statistik tersebut sebagai berikut:

Tabel 7 Data Statistik Tes Pratindakan

\begin{tabular}{cc}
\hline Statistik & Skor \\
\hline Mean & 40,33 \\
Median & 40,00 \\
Modus & 40 \\
Minimum & 33 \\
Maksimum & 53 \\
\hline Total & 968 \\
\hline
\end{tabular}

Dari tabel di atas dapat diuraikan bahwa data yang diperoleh dari 24 sampel diperoleh rata-rata sebesar 40,33 . Nilai yang sering muncul adalah 40 , nilai tengah adalah 40,00. Adapun nilai tertinggi atau maksimum adalah 53 dan nilai terendah adalah 33. Adapun total keseluruhan skor yang diperoleh adalah 968. Selanjutnya tabel frekuensi data pratindakan adalah sebagai berikut:

Tabel 8 Frekuensi Data Siklus I

\begin{tabular}{cccc}
\hline $\begin{array}{c}\text { Nilai } \\
\text { akhir }\end{array}$ & Frekuensi & Persentase & $\begin{array}{c}\text { Persentase } \\
\text { komulatif }\end{array}$ \\
\hline 33 & 4 & 16,7 & 16,7 \\
34 & 1 & 4,2 & 20,8 \\
37 & 2 & 8,3 & 29,2 \\
40 & 7 & 29,2 & 58,3 \\
41 & 2 & 8,3 & 66,7
\end{tabular}

\begin{tabular}{cccc}
43 & 3 & 12,5 & 79,2 \\
44 & 2 & 8,3 & 87,5 \\
47 & 1 & 4,2 & 91,7 \\
49 & 1 & 4,2 & 95,8 \\
53 & 1 & 4,2 & 100,0 \\
Total & 24 & 100 & \\
\hline
\end{tabular}

Dari tabel di atas dapat diuraikan bahwa nilai 34, 47, 49, 53, diperoleh masing-masing 1 orang sampel dengan persentase masing-masing $4,2 \%$. Selanjutnya untuk nilai 37, 41, dan 44 masing-masing diperoleh 2 orang dengan persentase $8,3 \%$. Untuk nilai 43 di peroleh 3 orang sampel dengan persentase $12,5 \%$. Selanjutnya untuk nilai 33 diperoleh empat orang dengan persentase 16,7 .

\section{Hasil Observasi Siklus I}

Selain data yang diperoleh melalui tes pratindakan juga diperoleh data hasil observasi. Data hasil observasi dibagi atas dua yaitu data observasi guru praktikan (peneliti) dan data observasi terhadap sampel. Lembar observasi ini dilakukan oleh guru kelas sebagai rekan kerja peneliti. Adapun hasil observasi pratindakan tersebut sebagai berikut: 


Kredo 4 (2021)
KREDO: Jurnal Ilmiah Bahasa dan Sastra
Terakreditasi Sinta 4 berdasarkan Keputusan
Direktorat Jenderal Penguatan Riset dan
Pengembangan, Kementerian Riset, Teknologi dan
Pendidikan Tinggi Republik Indonesia
Nomor: 23/E/KPT/2019. 08 Agustus 2019
https://jurnal.umk.ac.id/index.php/kredo/index

Tabel 9 Hasil Observasi Yang Diberikan Kepada Guru Praktikan (Peneliti)

\begin{tabular}{|c|c|c|c|c|c|}
\hline \multirow{2}{*}{$\begin{array}{c}\text { Aspek } \\
\text { yang } \\
\text { Dinilai } \\
\end{array}$} & \multicolumn{5}{|c|}{ Kategori } \\
\hline & $\mathrm{Sb}$ & B & $\mathrm{Cb}$ & $\mathrm{Kb}$ & $\mathrm{Tb}$ \\
\hline $\begin{array}{c}\text { Kemampu } \\
\text { an } \\
\text { membuka } \\
\text { pengajaran }\end{array}$ & & ya & & & \\
\hline $\begin{array}{l}\text { Proses } \\
\text { penyampai } \\
\text { an materi }\end{array}$ & ya & & & & \\
\hline $\begin{array}{l}\text { Interaksi } \\
\text { dengan } \\
\text { siswa }\end{array}$ & ya & & & & \\
\hline $\begin{array}{l}\text { Kemampu } \\
\text { an } \\
\text { pengelolah } \\
\text { an kelas }\end{array}$ & ya & & & & \\
\hline $\begin{array}{c}\text { Kemampu } \\
\text { an } \\
\text { penguasaa } \\
\text { n materi }\end{array}$ & ya & & & & \\
\hline $\begin{array}{c}\text { Kemampu } \\
\text { an } \\
\text { menutup } \\
\text { pelajaran }\end{array}$ & & $\mathrm{Ya}$ & & & \\
\hline
\end{tabular}

Dari tabel di atas dapat diuraikan

bahwa kemampuan peneliti dalam membuka pelajaran dinilai baik oleh guru ahli. Disamping itu kemampuan mentransformasikan materi kepada dinilai sangat baik. Selanjutnya interaksi yang dilakukan oleh peneliti kepada siswa dalam proses pembelajaran juga sangat baik, begitu pula dengan pengelolaan kelas dan penguasaan materi atau bahan pelajaran. Adapun kemampuan menutup pelajaran juga dalam kategori baik. Adapun hasil observasi terhadap sampel penelitian seperti yang terangkum dalam tabel berikut;

\section{9 | Jurnal Kredo}

Vol. 4 No. 22021
Tabel 10 Data Hasil Observasi Terhadap Siswa Sampel

\begin{tabular}{|c|c|c|c|c|c|}
\hline \multirow{2}{*}{$\begin{array}{c}\text { Aspek } \\
\text { yang } \\
\text { Dinilai }\end{array}$} & \multicolumn{5}{|c|}{ Kategori } \\
\hline & $\mathrm{Sb}$ & B & $\mathrm{Cb}$ & $\mathrm{Kb}$ & $\mathrm{Tb}$ \\
\hline $\begin{array}{l}\text { Antusias } \\
\text { siswa } \\
\text { mengikuti } \\
\text { pelajaran }\end{array}$ & & & Ya & & \\
\hline $\begin{array}{l}\text { Kemampu } \\
\text { an siswa }\end{array}$ & & & & & \\
\hline $\begin{array}{c}\text { mengkom } \\
\text { unikasika } \\
\text { n ide }\end{array}$ & & & Ya & & \\
\hline $\begin{array}{c}\text { Keaktifan } \\
\text { siswa } \\
\text { dalam } \\
\text { kelas }\end{array}$ & $\mathrm{Ya}$ & & & & \\
\hline $\begin{array}{c}\text { Keteramp } \\
\text { ilan } \\
\text { bertanya }\end{array}$ & & & Ya & & \\
\hline $\begin{array}{l}\text { Keteramp } \\
\text { ilan } \\
\text { menjawab }\end{array}$ & & Ya & & & \\
\hline $\begin{array}{l}\text { Keteramp } \\
\text { ilan } \\
\text { memberik } \\
\text { an solusi }\end{array}$ & & & Ya & & \\
\hline
\end{tabular}

Dari tabel di atas, dapat diuraikan bahwa antusias siswa saat mengikuti pelajaran pada siklus I cukup baik, siswa sudah mulai tertarik dengan materi, sudah muncul rasa bahagia, gembira dalam diri mereka. Kemampuan siswa mengkomunikasikan ide yang diamati sudah perlahan membaik dengan kategori cukup baik, siswa tidak hanya berperan sebagai pendengar pasif, di tahap ini siswa sudah mulai aktif dalam kegiatan pembelajaran. Keaktifan siswa dalam kelas dalam kegiatan pembelajaran 


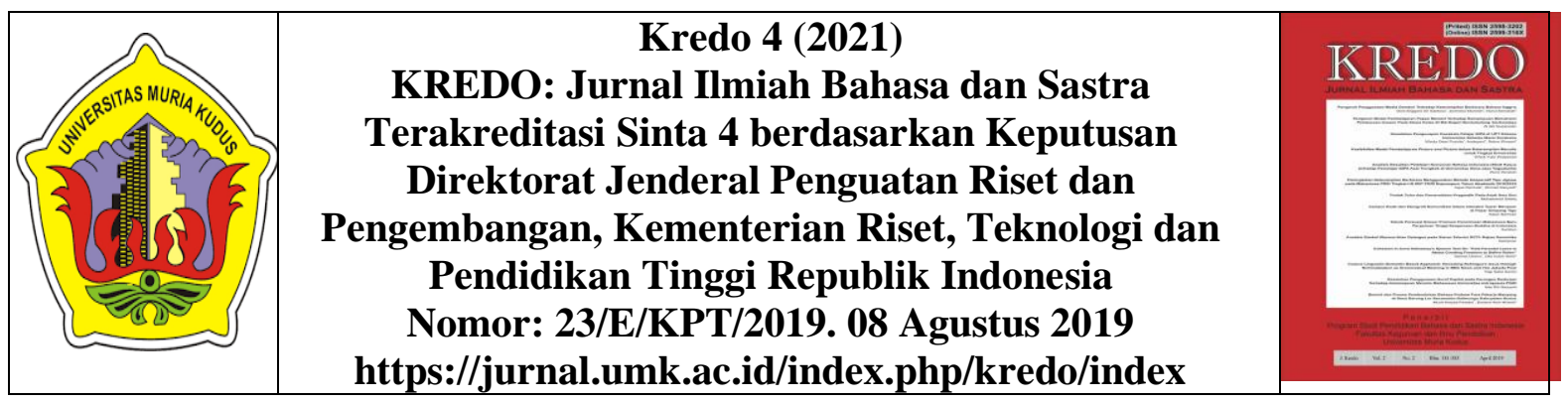

sangat baik, banyak siswa yang aktif, bukan hanya siswa yang dianggap unggul, melainkan mereka telah mampu membaur. Dari hasil observasi keterampilan bertanya siswa sudah cukup baik. Mereka tidak lagi cenderung menerima apa saja yang dijelaskan dan diperintahkan oleh guru. Hal serupa pun sama dengan kemampuan mejawab yang semakin baik. Kemampuan memberikan solusi juga berkembang menjadi cukup baik.

\section{E. Hasil Tes Siklus II}

Hasil tes Siklus I dimaksudkan untuk mengukur kemampuan tahap pertama siswa setelah memperoleh perlakuan awal dalam menulis cerita pendek. Ada tujuh aspek yang dinilai dalam tes tersebut. Aspek tersebut sesuai dengan aspek yang telah diuraikan sebelumnya. Adapun hasil tes tindakan siklus II tersebut adalah sebagai berikut;

Tabel 11 Rangkuman Hasil Tes Siklus II Menulis Cerita pendek

\begin{tabular}{c|c|c|c|c|c|c|c|c|c}
\hline \multirow{2}{*}{$\begin{array}{c}\text { Sa } \\
\text { el }\end{array}$} & 1 & 2 & 3 & 4 & 5 & 6 & 7 & $\begin{array}{c}\text { Sk } \\
\text { or } \\
\text { To } \\
\text { tal }\end{array}$ & $\begin{array}{c}\text { Sk } \\
\text { or } \\
\text { Ak } \\
\text { hir }\end{array}$ \\
\hline 01 & 80 & 80 & 60 & 60 & 80 & 70 & 60 & 70 & 70 \\
\hline 02 & 70 & 80 & 60 & 80 & 70 & 60 & 80 & $\begin{array}{c}70, \\
42\end{array}$ & 70 \\
\hline 03 & 70 & 60 & 80 & 60 & 70 & 70 & 80 & 70 & 70 \\
\hline 04 & 80 & 60 & 70 & 70 & 80 & 70 & 60 & 70 & 70 \\
\hline 05 & 70 & 80 & 80 & 70 & 70 & 80 & 60 & 70 & 70 \\
\hline 06 & 80 & 80 & 60 & 70 & 70 & 60 & 80 & $\begin{array}{c}74 \\
4\end{array}$ & 71 \\
\hline 07 & 80 & 70 & 60 & 80 & 70 & 80 & 60 & $\begin{array}{c}74 \\
2\end{array}$ & \\
\hline 08 & 70 & 80 & 70 & 80 & 70 & 60 & 80 & 72 & 73 \\
\hline
\end{tabular}

\begin{tabular}{|c|c|c|c|c|c|c|c|c|c|}
\hline & & & & & & & & $\begin{array}{l}, 8 \\
5\end{array}$ & \\
\hline 09 & 80 & 60 & 70 & 70 & 80 & 90 & 80 & $\begin{array}{c}75 \\
, 7 \\
7 \\
\end{array}$ & 76 \\
\hline 10 & 70 & 60 & 80 & 80 & 90 & 70 & 80 & $\begin{array}{l}75, \\
71\end{array}$ & 76 \\
\hline 11 & 70 & 80 & 80 & 90 & 80 & 70 & 70 & $\begin{array}{l}77, \\
14\end{array}$ & 77 \\
\hline 12 & 80 & 60 & 70 & 80 & 70 & 80 & 80 & $\begin{array}{l}74, \\
23\end{array}$ & 74 \\
\hline 13 & 80 & 60 & 80 & 70 & 80 & 90 & 70 & $\begin{array}{l}75, \\
71\end{array}$ & 76 \\
\hline 14 & 70 & 70 & 80 & 90 & 80 & 80 & 70 & $\begin{array}{l}77, \\
14\end{array}$ & 77 \\
\hline 15 & 70 & 90 & 80 & 60 & 80 & 70 & 80 & $\begin{array}{l}75, \\
71\end{array}$ & 76 \\
\hline 16 & 80 & 70 & 70 & 80 & 80 & 90 & 90 & 80 & 80 \\
\hline 17 & 80 & 70 & 90 & 80 & 80 & 90 & 80 & $\begin{array}{l}81, \\
42\end{array}$ & 81 \\
\hline 18 & 70 & 80 & 80 & 70 & 80 & 70 & 80 & $\begin{array}{l}75, \\
41\end{array}$ & 75 \\
\hline 19 & 80 & 70 & 60 & 70 & 70 & 80 & 70 & $\begin{array}{l}71, \\
42\end{array}$ & 71 \\
\hline 20 & 80 & 70 & 70 & 90 & 80 & 90 & 80 & 80 & 80 \\
\hline 21 & 70 & 90 & 90 & 80 & 70 & 70 & 80 & $\begin{array}{l}78, \\
57\end{array}$ & 79 \\
\hline 22 & 90 & 70 & 70 & 80 & 80 & 70 & 60 & $\begin{array}{l}74, \\
28\end{array}$ & 74 \\
\hline 23 & 70 & 90 & 80 & 70 & 90 & 70 & 80 & $\begin{array}{l}70, \\
57 \\
\end{array}$ & 71 \\
\hline 24 & 80 & 70 & 60 & 80 & 50 & 60 & 70 & $\begin{array}{l}67, \\
14\end{array}$ & 67 \\
\hline
\end{tabular}

Dari tabel rangkuman data di atas akan dibuatkan tabel frekuensi dan statistik. Tabel frekuensi akan memuat satuan-satuan skor yang diperoleh siswa, frekuensi perolehan setiap skor, persentase perolehan dan persentase komulatif. Selanjutnya pada data tabel statistik akan memuat rata-rata (mean), nilai tengah (median), nilai yang sering muncul (modus), nilai maksimal (maksimum), dan nilai minumal (minimum). Adapun tabel statistik tersebut sebagai berikut: 


Kredo 4 (2021)
KREDO: Jurnal Ilmiah Bahasa dan Sastra
Terakreditasi Sinta 4 berdasarkan Keputusan
Direktorat Jenderal Penguatan Riset dan
Pengembangan, Kementerian Riset, Teknologi dan
Pendidikan Tinggi Republik Indonesia
Nomor: 23/E/KPT/2019. 08 Agustus 2019
https://jurnal.umk.ac.id/index.php/kredo/index

Tabel 12 Data Statistik Tes Siklus II

\begin{tabular}{cc}
\hline Statistik & Skor \\
Mean & 73,96 \\
\hline Median & 74,00 \\
\hline Modus & 70 \\
\hline Minimum & 67 \\
\hline Maksimum & 87 \\
Total & 1775 \\
\hline Dari tabel di atas dapat diuraikan
\end{tabular}

bahwa data yang diperoleh dari 24 sampel diperoleh rata-rata sebesar 73,96 . Nilai yang sering muncul adalah 70 , nilai tengah adalah 74,00 . Adapun nilai tertinggi atau maksimum adalah 87 dan nilai terendah adalah 67. Adapun total keseluruhan skor yang diperoleh adalah 1775. Selanjutnya tabel frekuensi data pratindakan adalah sebagai berikut:

Tabel 13 Frekuensi Data Tindakan

\begin{tabular}{cccc}
\hline $\begin{array}{c}\text { Nilai } \\
\text { akhir }\end{array}$ & Frekuensi & Persentase & $\begin{array}{c}\text { Persentase } \\
\text { komulatif }\end{array}$ \\
\hline 67 & 1 & 4,2 & 4,2 \\
70 & 5 & 20,8 & 25,0 \\
71 & 4 & 16,7 & 41,7 \\
73 & 1 & 4,2 & 45,8 \\
74 & 2 & 8,3 & 54,2 \\
75 & 1 & 4,2 & 58,3 \\
76 & 4 & 16,7 & 75,0 \\
77 & 2 & 8,3 & 83,3 \\
79 & 1 & 4,2 & 87,5 \\
80 & 2 & 8,3 & 95.8 \\
81 & 1 & 4,2 & 100,0 \\
Total & 24 & 100 & \\
\hline
\end{tabular}

Dari tabel di atas dapat diuraikan bahwa nilai $67,73,75,79,81$ diperoleh masing-masing 1 orang sampel dengan persentase masing-masing 4,2\%. Selanjutnya untuk nilai 74,77 , dan 80 masing-masing di peroleh 2 orang dengan persentase $8,3 \%$. Untuk nilai 71 , dan 76 di peroleh masing-masing 4 orang sampel dengan persentase masing-masing $12,5 \%$. Selanjutnya untuk nilai 70 diperoleh lima orang dengan persentase 20,8 .

\section{F. Hasil Observasi Siklus II}

Selain data yang diperoleh melalui tes pratindakan juga diperoleh data hasil observasi. Data hasil observasi dibagi atas dua yaitu data observasi guru praktikan (peneliti) dan data observasi terhadap sampel. Lembar observasi ini dilakukan oleh guru kelas sebagai rekan kerja peneliti. Adapun hasil observasi pratindakan tersebut sebagai berikut:

Tabel 14 Hasil Observasi Yang Diberikan Kepada Guru Praktikan (Peneliti)

\begin{tabular}{|c|c|c|c|c|c|}
\hline \multirow{2}{*}{$\begin{array}{c}\text { Aspek yang } \\
\text { Dinilai }\end{array}$} & \multicolumn{5}{|c|}{ Kategori } \\
\hline & $\mathrm{Sb}$ & B & $\mathrm{Cb}$ & $\mathrm{Kb}$ & $\mathrm{Tb}$ \\
\hline $\begin{array}{c}\text { Kemampuan } \\
\text { membuka } \\
\text { pengajaran }\end{array}$ & & ya & & & \\
\hline $\begin{array}{c}\text { Proses } \\
\text { penyampaian } \\
\text { materi }\end{array}$ & ya & & & & \\
\hline $\begin{array}{c}\text { Interaksi } \\
\text { dengan siswa }\end{array}$ & $\mathrm{Ya}$ & & & & \\
\hline $\begin{array}{l}\text { Kemampuan } \\
\text { pengelolahan } \\
\text { kelas }\end{array}$ & $\mathrm{Ya}$ & & & & \\
\hline $\begin{array}{c}\text { Kemampuan } \\
\text { penguasaan } \\
\text { materi }\end{array}$ & $\mathrm{Ya}$ & & & & \\
\hline $\begin{array}{l}\text { Kemampuan } \\
\text { menutup } \\
\text { pelajaran }\end{array}$ & Ya & & & & \\
\hline
\end{tabular}

Dari tabel di atas dapat diuraikan bahwa kemampuan peneliti dalam membuka pelajaran dinilai baik oleh

\section{$341 \mid$ Jurnal Kredo \\ Vol. 4 No. 22021}




Kredo 4 (2021)
KREDO: Jurnal Ilmiah Bahasa dan Sastra
Terakreditasi Sinta 4 berdasarkan Keputusan
Direktorat Jenderal Penguatan Riset dan
Pengembangan, Kementerian Riset, Teknologi dan
Pendidikan Tinggi Republik Indonesia
Nomor: 23/E/KPT/2019. 08 Agustus 2019
https://jurnal.umk.ac.id/index.php/kredo/index

guru ahli. Disamping itu kemampuan mentransformasikan materi kepada dinilai sangat baik. Selanjutnya interaksi yang dilakukan oleh peneliti kepada siswa dalam proses pembelajaran juga sangat baik, begitu pula dengan pengelolaan kelas dan penguasaan materi atau bahan pelajaran. Adapun kemampuan menutup pelajaran semakin baik. Adapun hasil observasi terhadap sampel penelitian seperti yang terangkum dalam tabel berikut;

Tabel 15 Data Hasil Observasi Terhadap Siswa Sampel

\begin{tabular}{|c|c|c|c|c|c|}
\hline \multirow{2}{*}{$\begin{array}{c}\text { Aspek yang } \\
\text { Dinilai }\end{array}$} & \multicolumn{5}{|c|}{ Kategori } \\
\hline & $\mathrm{Sb}$ & B & $\mathrm{Cb}$ & $\mathrm{Kb}$ & $\mathrm{Tb}$ \\
\hline $\begin{array}{c}\text { Antusias siswa } \\
\text { mengikuti } \\
\text { pelajaran }\end{array}$ & ya & & & & \\
\hline $\begin{array}{l}\text { Kemampuan } \\
\text { siswa }\end{array}$ & & & & & \\
\hline $\begin{array}{l}\text { mengkomunik } \\
\text { asikan ide } \\
\text { Keaktifan }\end{array}$ & & $1 \mathrm{~d}$ & & & \\
\hline $\begin{array}{l}\text { siswa dalam } \\
\text { kelas }\end{array}$ & $\mathrm{Ya}$ & & & & \\
\hline $\begin{array}{l}\text { Keterampilan } \\
\text { bertanya }\end{array}$ & Ya & & & & \\
\hline $\begin{array}{l}\text { Keterampilan } \\
\text { menjawab }\end{array}$ & & $\mathrm{Ya}$ & & & \\
\hline $\begin{array}{c}\text { Keterampilan } \\
\text { memberikan } \\
\text { solusi }\end{array}$ & & $\mathrm{Ya}$ & & & \\
\hline
\end{tabular}

Dari tabel di atas, dapat diuraikan

bahwa antusias siswa saat mengikuti pelajaran pada siklus II sangat baik, siswa sangat tertarik dengan materi, sudah muncul rasa bahagia, gembira dalam diri mereka. Kemampuan siswa mengkomunikasikan ide yang diamati sudah perlahan membaik dengan kategori baik, siswa tidak hanya berperan sebagai pendengar pasif, di tahap ini siswa sudah mulai aktif dalam kegiatan pembelajaran dan menunjukkan fungsi dan peran dirinya dalam PBM. Keaktifan siswa dalam kelas dalam kegiatan pembelajaran sangat baik, banyak siswa yang aktif, bukan hanya siswa yang dianggap unggul, melainkan mereka telah mampu membaur. Dari hasil observasi keterampilan bertanya siswa sudah cukup baik. Mereka tidak lagi cenderung menerima apa saja yang dijelaskan dan diperintahkan oleh guru. Hal serupa pun sama dengan kemampuan mejawab yang semakin baik. Kemampuan memberikan solusi juga berkembang menjadi lebih baik.

\section{G. Analisis Data}

1. Analisis Data Pra Tindakan

Tabel 16 Kategori Data Hasil Tes Pra Tindakan

\begin{tabular}{ccc}
\hline $\begin{array}{c}\text { Nilai } \\
\text { Akhir }\end{array}$ & Frekuensi & Kategori \\
\hline 21 & 1 & Kurang \\
23 & 1 & Kurang \\
26 & 1 & Kurang \\
30 & 5 & Kurang \\
31 & 3 & Kurang \\
33 & 3 & Kurang \\
33 & 1 & Kurang \\
34 & 2 & Kurang \\
35 & 1 & Kurang \\
36 & 1 & Kurang \\
36 & 1 & Kurang \\
37 & 2 & Kurang \\
40 & 1 & Kurang \\
41 & 1 & Kurang \\
Total & 24 & Kurang \\
\hline
\end{tabular}

Dari tabel di atas dapat diuraikan 


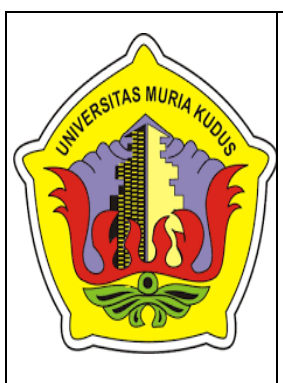

Kredo 4 (2021)

KREDO: Jurnal Ilmiah Bahasa dan Sastra

Terakreditasi Sinta 4 berdasarkan Keputusan

Direktorat Jenderal Penguatan Riset dan

Pengembangan, Kementerian Riset, Teknologi dan

Pendidikan Tinggi Republik Indonesia

Nomor: 23/E/KPT/2019. 08 Agustus 2019

https://jurnal.umk.ac.id/index.php/kredo/index

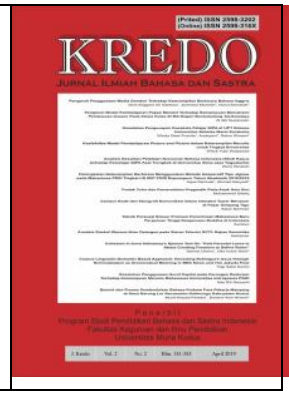

bahwa kemampuan semua sampel dalam menulis cerita pendek masih kurang Atau sangat rendah. Skor tertinggi adalah 41 dan skor terendah adalah 21.

2. Analisis Data Hasil Siklus I

Tabel 17 Kategori Data Hasil Tes Siklus I

\begin{tabular}{ccc}
\hline $\begin{array}{c}\text { Nilai } \\
\text { akhir }\end{array}$ & Frekuensi & Kategori \\
\hline 33 & 4 & Kurang \\
34 & 1 & Kurang \\
37 & 2 & Kurang \\
40 & 7 & Kurang \\
41 & 2 & Kurang \\
43 & 3 & Kurang \\
44 & 2 & Kurang \\
47 & 1 & Kurang \\
49 & 1 & Kurang \\
53 & 1 & Kurang \\
Total & 24 & \\
\hline
\end{tabular}

Dari tabel di atas dapat diuraikan bahwa kemampuan semua sampel dalam menulis cerita pendek masih kurang atau sangat rendah. Skor tertinggi adalah 53 dan skor terendah adalah 33. Jika dibandingkan dari hasil pratindakan, siklus I mengalami peningkatan namun tidak terlalu besar. Siswa masih dianggap kurang mampu menulis cerita pendek.

3. Analisis Data Hasil Siklus II

Tabel 18 Kategori Data Hasil Tes Siklus II

\begin{tabular}{ccc}
\hline $\begin{array}{c}\text { Nilai } \\
\text { akhir }\end{array}$ & Frekuensi & Kategori \\
\hline 67 & 1 & Cukup \\
70 & 5 & Cukup \\
71 & 4 & Cukup \\
73 & 1 & Cukup \\
74 & 2 & Cukup \\
75 & 1 & Baik \\
76 & 4 & Baik \\
77 & 2 & Baik
\end{tabular}

\begin{tabular}{ccc}
79 & 1 & Bai \\
80 & 2 & Bai \\
81 & 1 & Bai \\
Total & 24 & \\
\hline
\end{tabular}

Baik

Baik

Dari Tabel di atas dapat kita uraikan bahwa pada siklus II memperoleh hasil yang jauh lebih baik dari siklus I dan pratindakan. Dari 24 sampel 13 orang siswa memproleh skor cukup baik, dan 11 di antaranya memperoleh skor baik. Nilai tertinggi pada siklus II ini adalah 81 dan nilai terendah adalah 67.

4. Rangkuman Perbandingan Hasil Tes Pratindakan Siklus I dan II

Setelah dideskripsikan kemampuan menulis cerita pendek siswa dan pengkategoriannya, maka selanjutnya akan dibandingkan hasil akhir dari ketiga tahap tes tersebut. Adapun hasil perbandingannya seperti pada tabel berikut;

Tabel 19 Rangkuman Perbandingan Hasil Tes Pratindakan Siklus I dan Siklus II

\begin{tabular}{cccc}
\hline Statistik & $\begin{array}{c}\text { Pra } \\
\text { Tindakan }\end{array}$ & Siklus I & Siklus II \\
\hline Mean & 32,36 & 40,33 & 73,96 \\
Median & 32,85 & 40,00 & 74,00 \\
Modus & 30 & 40 & 70 \\
Minimum & 21 & 33 & 67 \\
Maksimum & 41 & 53 & 87 \\
Total & 777 & 968 & 1775 \\
\hline
\end{tabular}

Dari tabel di atas dapat diuraikan bahwa hasil rata-rata yang diperoleh dari setiap tes berbeda-beda. Pada tahap pratindakan sebesar 32,36, siklus I sebesar 40,33, dan pada siklus II sebesar 73,96. Selisih antara pratindakan terhadap siklus I, siklus I terhadap

\section{3 | Jurnal Kredo}

Vol. 4 No. 22021 


Kredo 4 (2021)
KREDO: Jurnal Ilmiah Bahasa dan Sastra
Terakreditasi Sinta 4 berdasarkan Keputusan
Direktorat Jenderal Penguatan Riset dan
Pengembangan, Kementerian Riset, Teknologi dan
Pendidikan Tinggi Republik Indonesia
Nomor: 23/E/KPT/2019. 08 Agustus 2019
https://jurnal.umk.ac.id/index.php/kredo/index

siklus II masing-masing 7,97 dan 33,63. Adapun nilai tengah atau media menunjukkan peningkatan dari setiap tahap tes tersebut yaitu 32,83 menjadi 40,00, dan mencapai tahap berhasil pada nilai tengah 74,00. Selanjutnya nilai yang sering muncul dari ketiga tahap penilaian ini masing-masing 30,40 , dan 70. Begitu pula dengan nilai minimal dan masimal ketiga tahap penilaian tersebut sangat menunjukkan kemajuan yaitu pada nilai minimum berturut-turut 21, 33, 67, dan nilai maksimumnya adalah 41, 53, dan 87. Jadi dapat disimpulkan bahwa pada tahap pratindakan kemampuan siswa menulis cerita pendek sangat rendah, namun ketika dilakukan pembelajaran menulis cerita pendek dengan pendekatan partisipatoris, pada siklus I mengalami peningkatan namun masih tergolong rendah. Baru pada siklus ke II dengan memperhatikan kekurangan dan kelemahan pada siklus ke I maka diperoleh hasil yang memuaskan dengan kategir bahwa pada siklus ke II dinyatakan berhasil.

\section{PEMBAHASAN}

Sampel yang digunakan pada kelas ini adalah sampel acak yang namanya tidak dicantumkan tetapi dengan menggunakan kode angka. Setelah data diperoleh melalui tes dan observasi maka data tersebut diolah dan dianalisis. Hasil analisis membuktikan bahwa pada tahap pratindakan kemampuan siswa dalam menulis cerita pendek masih sangat rendah.

Ada beberapa hal yang menjadi perhatian peneliti saat kedua siklus dilaksanakan bahwa ada tiga tahapan kegiatan pembelajaran yaitu tahap perencanaan program (program planning), pelaksanaan (program implementtion), dan penilaian (program evaluation) kegiatan pembelajaran. Ketiga tahap ini teraplikasi dalam pelaksanaan pembelajaran partisipatoris.

$$
\text { Pada tahap perencanaan }
$$

keterlibatan peserta didik diwujudkan dalam kegiatan mengidentifikasi kebutuhan belajar, sumber-sumber atau potensi yang tersedia, permasalahan dan prioritas masalah, dan kemungkinan hambatan dalam pembelajaran. Kebutuhan belajar dinyatakan oleh peserta didik sebagai keinginan yang dirasakan untuk memperoleh pengetahuan, keterampilan, sikap dan atau nilai yang diperlukan dalam kehidupan atau tanggung jawab pekerjaannya. Kebutuhan-kebutuhan belajar tersebut kemudian ditata secara cermat dan berurutan. Selanjutnya ditentukan urutan prioritas kebutuhan belajaran atas dasar kepentingan dan kesegeraannya untuk dipenuhi melalui kegiatan belajar.

Selanjutnya peserta didik dilibatkan dalam merumuskan tujuan belajar. Tujuan belajar merupakan pernyataan mengenai apa yang akan dicapai atau diperoleh peserta didik 


Kredo 4 (2021)
KREDO: Jurnal Ilmiah Bahasa dan Sastra
Terakreditasi Sinta 4 berdasarkan Keputusan
Direktorat Jenderal Penguatan Riset dan
Pengembangan, Kementerian Riset, Teknologi dan
Pendidikan Tinggi Republik Indonesia
Nomor: 23/E/KPT/2019. 08 Agustus 2019
https://jurnal.umk.ac.id/index.php/kredo/index

melalui kegiatan belajar. Tujuan belajar berkaitan erat dengan kebutuhan belajar. Perolehan belajar itu dapat berupa pengetahuan, keterampilan, dan atau nilai-nilai yang menjadi bagian dari kehidupan peserta didik. Untuk mencapai tujuan belajar itu akan ditetapkan program pembelajaran. Program pembelajaranegiatan ini mencakup apa yang akan dipelajari, metode dan teknik pembelajaran, evaluasi proses dan hasil belajar, alatalat dan fasilitas, waktu yang digunakan, dan lain sebagainya. Singkatnya, keikutsertaan peserta didik dalam tahap perencanaan kegiatan pembelajaran meliputi identifikasi kebutuhan belajar, sumber-sumber yang tersedia dan kemungkinan hambatan yang akan ditemui dalam kegiatan pembelajaran, penyusunan prioritas kebutuhan, perumusan tujuan belajar dan penetapan program kegiatan pembelajaran.

Pada tahap pelaksanaan program pembelajaran peserta didik dilibatkan dalam menciptakan iklim yang kondusif untuk belajar. Iklim yang kondusif ini mencakup pertama, kedisiplinan peserta didik yang ditandai dengan keteraturan dalam kehadiran pada setiap kegiatan pembelajaran. Kedua, pembinaan hubungan antar peserta didik dan antara peserta didik dengan pendidik sehingga tercipta hubungan kemanusiaan yang terbuka, akrab, terarah, saling menghargai, saling membantu, dan saling belajar. Ketiga, interaksi kegiatan pembelajaran antara peserta didik dan pendidik dilakukan melalui hubungan horizontal. Hubungan ini menggambarkan terjalinnya komunikasi yang sejajar baik antara peserta didik dengan pendidik maupun antar peserta didik. Keempat, tekanan kegiatan pembelajaran adalah pada peranan peserta didik yang lebih aktif melakukan kegiatan pembelajaran, bukan pada pendidik yang lebih mengutamakan kegiatan mengajar. Pendekatan kegiatan pembelajaran berpusat pada peserta didik, tidak terpusat pada pendidik. Penyusunan bahan belajar dan penentuan langkah-langkah kegiatan pembelajaran dilakukan oleh para peserta didik bersama pendidik atau oleh para peserta didik dengan bimbingan pendidik. Peranan pendidik ialah membantu peserta didik dalam melakukan kegiatan pembelajaran. Secara singkat dapat dikemukakan bahwa situasi kegiatan pembelajaran yang dapat mengembangkan interaksi yang efektif dapat ditumbuhkan apabila peserta didik ikut serta secara aktif dalam pelaksanaan program kegiatan pembelajaran.

Pada tahap evaluasi program pembelajaran peserta didik dilibatkan dalam menetukan apa yang akan dievaluasi, bagaimana evalusi dilakukan, dan kapan saja evaluasi akan dilakukan. Selain itu peserta didik juga dilibatkan dalam pelaksanaan evaluasi. Evaluasi dapat digunakan baik untuk penilaian pelaksanaan pembelajaran

\section{5 | Jurnal Kredo}

Vol. 4 No. 22021 


Kredo 4 (2021)
KREDO: Jurnal Ilmiah Bahasa dan Sastra
Terakreditasi Sinta 4 berdasarkan Keputusan
Direktorat Jenderal Penguatan Riset dan
Pengembangan, Kementerian Riset, Teknologi dan
Pendidikan Tinggi Republik Indonesia
Nomor: 23/E/KPT/2019. 08 Agustus 2019
https://jurnal.umk.ac.id/index.php/kredo/index

maupun untuk penilaian pengelolaan program pembelajaran. Penilaian pelaksanaan pembelajaran mencakup penilaian terhadap proses, hasil, dan dampak pembelajaran. Penilaian terhadap proses pembelajaran untuk mengetahui sejauhmana kesesuaian antara poses yang telah direncanakan denagan pelaksanaannya. Penilaian terhadap hasil pembelajaran untuk mengetahui mengenai perubahan perilaku (pengetahuan, keterampilan, nilai, aspirasi) yang dialami peserta didik setelah mengikuti program pembelajaran. Penilaian terhadap dampak pembelajaran adalah untuk mengetahui perubahan kehidupan lulusan setelah menerapkan hasil belajarnya seperti dalam perolehan atau peningkatan pendapatan, pembelajaran orang lain, dan keikutsertaannya dalam pembangunan masyarakat. Evaluasi terhadap pengelolaan program pembelajaran dilakukan untuk menilai perencanaan, pelaksanaan dan pengembangan program pembelajaran.

Oleh karena itu dilakukan perlakuan pada siklus I dan diperoleh hasil yang lebih baik dari hasil pratindakan, tetapi masih dalam kategori kurang baik. Melihat hal tersebut maka kembali dilakukan perlakuan pada siklus ke II dengan memperhatikan kelemahan dan kekurangan pada siklus I. Adapun hasil tes setelah dilakukan perlakuan pada siklus ke II maka kemampuan siswa dalam menulis surat mengalami perkembangan yang sangat signifikan. Di mana pada siklus ke II kemampuan siswa dalam menulis cerita pendek masuk dalam kategori baik.

\section{SIMPULAN}

Kesimpulan yang ditarik dari hasil penelitian ini adalah sebagai berikut :

1. Setelah dilakukan perlakuan kepada kelas yang dijadikan sampel melalui siklus I dan siklus II diketahui bahwa siklus I menandai adanya peningkatan dari tes pratindakan. Selanjutnya siklus II menandai adanya peningkatan dari siklus I. Hal tersebut membuktikan bahwa peningkatan keterampilan menulis teks berita dengan pendekatan partisipatoris dalam dua siklus dinyatakan berhasil.

2. Hasil penelitian membuktikan bahwa keterampilan menulis teks berita siswa VII F SMPN 3 Makassar akan meningkat apabila dalam pembelajarannya menggunakan pendekatan partisipatoris. $\mathrm{Hal}$ tersebut dibuktikan dengan hasil ratarata, nilai tengah, nilai yang sering muncul, serta nilai maksimal pada tes pratindakan, siklus I, siklus II, membuktikan adanya peningkatan.

\section{SARAN}

Berdasarkan pada simpulan hasil penelitian tersebut, peneliti memberikan 


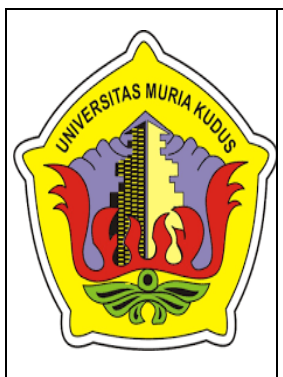

Kredo 4 (2021)

KREDO: Jurnal Ilmiah Bahasa dan Sastra

Terakreditasi Sinta 4 berdasarkan Keputusan

Direktorat Jenderal Penguatan Riset dan

Pengembangan, Kementerian Riset, Teknologi dan

Pendidikan Tinggi Republik Indonesia

Nomor: 23/E/KPT/2019. 08 Agustus 2019

https://jurnal.umk.ac.id/index.php/kredo/index

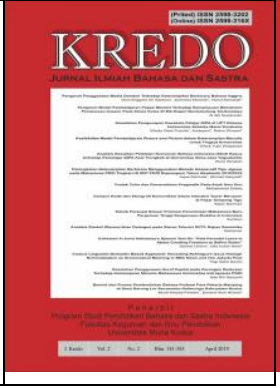

saran sebagai berikut: Para guru Bahasa Indonesia berperan aktif sebagai inovator untuk memilih teknik pembelajaran yang paling tepat sehingga pembelajaran yang dilaksanakan menjadi pengalaman yang bermakna bagi siswa. Para guru bahasa Indonesia dapat menggunakan pendekatan partisipatoris dalam membelajarkan keterampilan menulis teks berita. Pembelajaran dengan pendekatan partisipatoris dapat dijadikan alternatif pilihan bagi guru bidang studi lain dalam membelajarkan bidang garapannya. Para praktisi atau peneliti di bidang pendidikan dan bahasa dapat melakukan penelitian serupa dengan teknik pembelajaran yang berada sehingga didapatkan berbagai alternatif teknik pembelajaran menulis.

\section{DAFTAR PUSTAKA}

Dalman, H. 2021. Keterampilan menulis. PT. Raja Grafindo Persada.

Hutagalung, I. 2017. Pengaruh Model Pembelajaran dan Motivasi Belajar Terhadap Hasil Belajar Menulis Surat Pribadi (Personalicher Brief) Mahasiswa Semester II (Dua) Program Studi Pendidikan Bahasa Jerman FKIP Universitas HKBP Nommensen Tahun Ajaran 2016/2017.

Indonesia, U.-U. R. 2003. Sistem Pendidikan Nasional. Jakarta: Direktorat Pendidik Menengah Umum.

Julaeha, S. 2019. Problematika Kurikulum dan Pembelajaran Pendidikan Karakter. Jurnal Penelitian Pendidikan Islam,[SL], 7(2), 157-182.

Minderop, A. 2010. Psikologi Sastra: Karya, Metode, Teori, dan Contoh Kasus. Yayasan Pustaka Obor Indonesia.

Pramesthi, A. R. 2011. Pemanfaatan Teenlit sebagai Alternatif Bahan Pembelajaran Apresiasi Sastra untuk Siswa SMA. Universitas Negeri Semarang.

Raditiyanto, S. 2018. Kehidupan Rumah Tangga Ni Krining dan Adji Punarbawa Dalam Cerpen Malam Pertama Calon Pendeta Karya Gde Aryantha Soethama (Analisis Sosiologi Sastra). Media Komunika (Jurnal Komunikasi) Universitas Sangga Buana $Y P K P$, $3(1)$, $14-24$. 


Kredo 4 (2021)
KREDO: Jurnal Ilmiah Bahasa dan Sastra
Terakreditasi Sinta 4 berdasarkan Keputusan
Direktorat Jenderal Penguatan Riset dan
Pengembangan, Kementerian Riset, Teknologi dan
Pendidikan Tinggi Republik Indonesia
Nomor: 23/E/KPT/2019. 08 Agustus 2019
https://jurnal.umk.ac.id/index.php/kredo/index

Sadari, S. 2015. Model-Model Pengajaran dan Pembelajaran Islami (Studi Analisis Pembelajaran Mandiri). Waratsah, 1(1).

Sari, T. D. A. 2015. Penerapan Teknik Pembelajaran Partisipatif untuk Meningkatkan Kemampuan Berbicara Bahasa Arab: Studi Quasi Eksperiment Terhadap Siswa kelas X Madrasah Aliyah Al-Inayah Bandung. Universitas Pendidikan Indonesia.

Semi, M. A. 2007. Dasar-Dasar Keterampilan Menulis. Bandung: Angkasa.

Wibawa, B. 2003. Penelitian Tindakan Kelas. Jakarta: Dirjen Dikdasmen, 2572-2721. 